\title{
"Managing energy consumption: a case of natural gas as a taxation tool in Ukraine"
}

\begin{tabular}{|c|c|}
\hline \multirow{5}{*}{ AUTHORS } & Anatoliy Goncharuk iD http://orcid.org/0000-0001-9870-4679 \\
\hline & R http://www.researcherid.com/rid/M-8580-2015 \\
\hline & \multirow{2}{*}{$\begin{array}{l}\text { Aleksandra Figurek } \\
\text { Vyacheslav Truba id https://orcid.org/0000-0001-7782-2166 }\end{array}$} \\
\hline & \\
\hline & Iryna Nyenno iD https://orcid.org/0000-0003-0762-808X \\
\hline ARTICLE INFO & $\begin{array}{l}\text { Anatoliy Goncharuk, Aleksandra Figurek, Vyacheslav Truba and Iryna Nyenno } \\
\text { (2019). Managing energy consumption: a case of natural gas as a taxation tool in } \\
\text { Ukraine. Problems and Perspectives in Management, 17(4), 360-369. } \\
\text { doi:10.21511/ppm.17(4).2019.29 }\end{array}$ \\
\hline DOI & http://dx.doi.org/10.21511/ppm.17(4).2019.29 \\
\hline RELEASED ON & Thursday, 26 December 2019 \\
\hline RECEIVED ON & Thursday, 26 September 2019 \\
\hline ACCEPTED ON & Monday, 23 December 2019 \\
\hline & $(\mathrm{cc}) \overline{\mathrm{EY}}$ \\
\hline LICENSE & $\begin{array}{l}\text { This work is licensed under a Creative Commons Attribution } 4.0 \text { International } \\
\text { License }\end{array}$ \\
\hline JOURNAL & "Problems and Perspectives in Management" \\
\hline ISSN PRINT & $1727-7051$ \\
\hline ISSN ONLINE & $1810-5467$ \\
\hline PUBLISHER & LLC "Consulting Publishing Company "Business Perspectives" \\
\hline FOUNDER & LLC "Consulting Publishing Company "Business Perspectives" \\
\hline & ニニ: \\
\hline NUMBER OF REFERENCES & NUMBER OF FIGURES \\
\hline 28 & 0 \\
\hline
\end{tabular}

(C) The author(s) 2021. This publication is an open access article. 


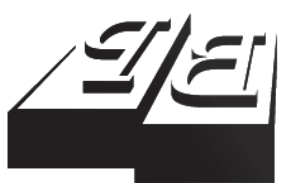

BUSINESS PERSPECTIVES

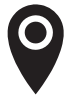

LLC "CPC "Business Perspectives" Hryhorii Skovoroda lane, 10, Sumy, 40022, Ukraine

www.businessperspectives.org

Received on: $26^{\text {th }}$ of September, 2019 Accepted on: $23^{\text {rd }}$ of December, 2019

(C) Anatoliy Goncharuk, Aleksandra Figurek, Vyacheslav Truba, Iryna Nyenno, 2019

Anatoliy Goncharuk, Ph.D., Dr. habil., Professor, Department of Business Administration and Corporate Security, International Humanitarian University, Ukraine.

Aleksandra Figurek, Ph.D., Associate Professor, University of Banja Luka, Bosnia and Herzegovina.

Vyacheslav Truba, Ph.D., Dean, Odessa I.I. Mechnikov National University, Ukraine.

Iryna Nyenno, Ph.D., Dr. habil. Odessa I.I. Mechnikov National University, Ukraine.

\section{(ㄷ)(i)}

This is an Open Access article, distributed under the terms of the Creative Commons Attribution 4.0 International license, which permits unrestricted re-use, distribution, and reproduction in any medium, provided the original work is properly cited.
Anatoliy Goncharuk (Ukraine), Aleksandra Figurek (Bosnia and Herzegovina), Vyacheslav Truba (Ukraine), Iryna Nyenno (Ukraine)

\section{MANAGING ENERGY CONSUMPTION: A CASE OF NATURAL GAS AS A TAXATION TOOL IN UKRAINE}

\begin{abstract}
Energy consumption is managed to some degree in different countries. If the government is interested in reducing the energy poverty and increasing the energy consumption, it provides enough energy access for all consumers. However, sometimes, in order to regulate the energy market properly, the government should pursue other goals, i.e., political, economic, or even fiscal. This study aims to figure out how the new natural gas policy of Ukrainian government reflects on the main stakeholders' incomes and expenses: the profits of domestic gas companies; the expenses of the four main groups of households by income. The article shows the case of unfair taxation of households natural gas consumption by the Ukrainian government that was named by the authors as "gas tax." Analyzing this case using the statistical indicators of dynamics, distribution and structure, it was found out that the honest taxpayers who receive middle incomes (middle class) are in the most disadvantaged position because they are forced to pay the highest price and the largest share of their income for utilities. The paper also includes distinguishing several shortcomings and ethical problems that appear during application of the gas tax in Ukraine: growth of cost inflation, reduction in domestic consumption, reducing the profitability of business; reducing the middle class and increasing the stratification of society, concealment of real incomes and growth of the shadow economy, enhancing injustice and labor migration abroad. All these problems are the arguments for reconsidering gas tax to make it fair and less painful for the economy and households.
\end{abstract}

\section{Keywords energy poverty, natural gas, households, middle class, Ukraine}

\section{JEL Classification L95, Q48, H31}

\section{INTRODUCTION}

Energy consumption is managed to some degree in different countries. However, in countries with insufficient extraction of their energy carriers, the problem of energy consumption management is particularly acute. However, in all the countries, there is a confrontation: consumers (households and organizations) want to get enough energy at affordable prices, while suppliers try to sell energy at the highest possible prices. In the energy market, the government often plays a key role as a regulator. Moreover, as a rule, the price of energy sold on the market of a particular country depends on the regulatory policy. If the government is interested in reducing the energy poverty (Bouzarovski, 2014) and increasing the energy consumption (Thomas \& Rosenow, 2019), it provides enough energy access for all consumers. However, sometimes, regulating the energy market, the government may pursue other goals, i.e., political, economic, or even fiscal. One of the most politicized energy resources is natural gas, which this article is dedicated to. 
In the last decades, natural gas has become one of the means of political and economic pressure. The term "gas war," which was originally an attribute of chemical warfare, now is increasingly used in literature and everyday life in a different, indirect sense. Bolivia in 2003 (Perreault, 2008) and Russia in 2014 (Pigliucci, 2016) are the most known cases of "gas war." Until now, natural gas has been used as a tool in such wars for international pressure in order to obtain political and economic concessions.

However, in recent years, another aspect of pressure using natural gas has emerged - fiscal pressure. It involves the use of inflated gas prices as an additional tool for taxation. This new role of natural gas is being tested by the Ukrainian government, implementing the program of cooperation with the International Monetary Fund (IMF).

In conditions of the high level of the shadow economy, the traditional tax instruments have a weakened impact on public finances. When the tax base is low, the traditional raising taxes do not lead to an appropriate increase in tax revenues. However, Ukraine has high external debt and can only avoid a default by attracting billions of dollars during the year. The IMF agreed to provide Kyiv with a new US $\$ 3.9$ billion tranche of aid, which will be released over the next 14 months (Stankova, 2018). However, the main condition of this tranche is a rise in natural gas prices for householders by $60 \%$.

The government agreed to increase household gas price by $23.5 \%$ up to USD 305 per 1,000 cubic meters from November 2018 (Government, 2018). A further significant hike in household rates is expected from January 2020 (NERC, 2019). Tymoshenko (2018), ex-prime minister of Ukraine, labeled this move a "crime" and "genocide towards the Ukrainian people," warning that "most families simply will not survive the winter" with higher prices.

Is the rise in gas prices for households so tragic? Are all the Ukrainian households losing or is the effect of gas price increases selective and targeted?

This study, attempts to answer all the above mentioned questions from a fiscal point of view.

\section{LITERATURE REVIEW}

As Goncharuk and lo Storto (2017) found, Ukrainian natural gas sector is low-performing in terms of operators' technical and scale efficiency, hence, there is a room to design more efficient market configurations. Among the issues needed attention to developing an effective gas market policy, these authors supposed that "while greater efficiency is necessary to reduce cost and increase service quality, at different stages of progress of the reform process other goals may be more important" (Goncharuk \& lo Storto, 2017, p. 464). It seems that precisely fiscal goals currently prevail in the Ukrainian gas market.

Considering the appropriate literature, several publications were found that are more or less relevant to considering the problem with two key aspects.
On the one hand, the problem of a sharp rise in the price of natural gas on the domestic market can be seen as an increase in the country's energy poverty, which manifests itself in a lesser availability of this resource for households. Bouzarovski and Tirado Herrero (2017) defined energy poverty as the inability of a household to secure a socially and materially necessitated level of energy services in the household. Bollino and Botti (2018) developed a synthetic indicator of energy poverty to access the households' well-being across different domains of inequality in access to energy services and to a healthy domestic environment. However, they are not considering natural gas separately, focusing on the availability of energy and thermal efficiency - the two main manifestations of energy poverty. In another study, Lenz and Grgurev (2016) found that energy poverty has become a rising issue in Croatia, where natural gas inevitably (by $28 \%$ ) impacted the occurrence the energy poverty. 
Thus, the increase in natural gas prices to a certain extent enhances the energy poverty, which is reflected in the ability of households to receive enough energy for full-fledged life. In some cases, it can lead to household gas savings, e.g., to $4 \%$ reduction of natural gas used in the boiler room for the house's heating in Poland (Krawczyk, 2016). However, mainly energy prices increase leads to annual expenditure on energy for European households rise in nearly all member states, with a significant variation between, and even within, countries (Grave et al., 2016).

On the other hand, the natural gas prices increase may enhance a social inequality. So, Preotesi (2016) found in Romania that an increase of natural gas prices strongly affects the budget of poor households that enhances a social inequality. However, an effective government subsidy policy for poor households can counteract this negative effect. Moreover, such subsidies are provided in several countries, including Ukraine. However, subsidy payments are often made to regional distribution companies controlled by oligarchs known in the Ukrainian language as "oblhazy" through their subsidiary retailers known as "hazzbuty," and not directly to consumers, which facilitates the use of the system with false claims (Saha \& Zaslavskiy, 2018). Since the end of 2017, the Cabinet of Ministers of Ukraine announced a change that will transfer the subsidy payments from "hazzbuty" to households.

But how fair is this subsidy? Unfortunately, there is no answer to this question in the literature.
Therefore, this study attempted to figure out how the new natural gas policy of Ukrainian government reflects on the main stakeholders' incomes and expenses:

- the profits of domestic gas companies;

- the expenses of the four main groups of households by income.

\section{THE METHODOLOGY}

In this study, the theoretical and empirical methods are used to determine the impact of the current Ukrainian public gas pricing policy on domestic households. In particular, the following indicators and tools were used:

- $\quad$ statistical indicators of dynamics, e.g., profitability growth rate (annual) in percent;

- distribution indicators, e.g., distribution of people by monthly income per capita;

- statistical indicators of structure, e.g. the share of utilities rate; and

- other tools that help achieve the objectives of the study.

The research methodology is arranged in the following order (Figure 1).

First, trends in the natural gas market, in particular, the profitability of domestic gas companies,

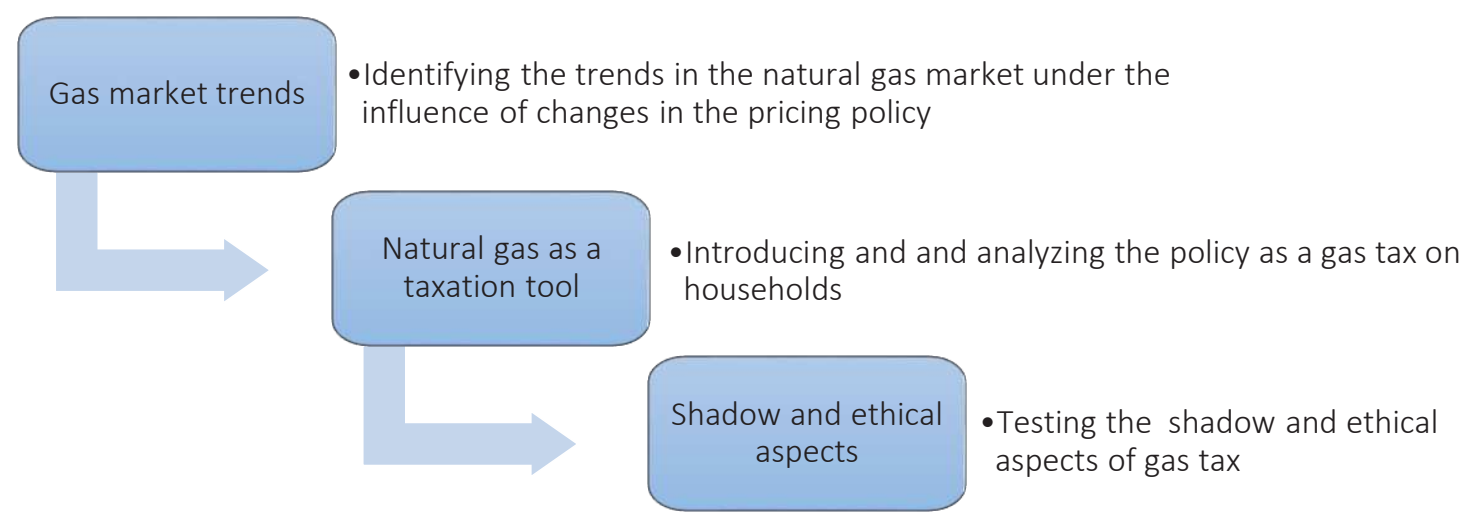

Figure 1. The research methodology 
are identified under the influence of changes in the state's pricing policy.

Then, a new policy is introduced and analyzed as a gas tax on households, i.e., fiscal tool.

Finally, on the cases, the justice of such a new tax will be tested and its shadow and ethical aspects will be considered.

\section{THE RESULTS}

\subsection{Ukrainian natural gas market}

Natural gas is one of the most important energy resources for the Ukrainian economy. Its internal sources in a total are less than industrial needs, but they are enough for household and utility services consumption. Until 2014, Ukraine covered the internal deficit of natural gas by import from Russia. However, during the military conflict and "gas war" with Russia in 2014, Ukraine refused from the Russian gas and reoriented to supplies from the EU countries.

Implicit subsidies to households through underpriced household gas and heating tariffs had been a prevailing policy in Ukraine. However, they were increasingly costly. Moreover, in the opinion of the IMF experts (Mitra \& Atoyan, 2012), while low tariffs supported poor households, they disproportionately favored those who consume the most, typically, wealthy households.

That is why IMF demanded, as part of the terms for getting extra financial aid, to increase gas pric- es to a consumer by $280 \%$, and $66 \%$ for heating. The Ukrainian government agreed and dramatically raised the prices (Duvignau, 2015).

Budget revenues of Ukraine are not enough due to the dramatic reduction in GDP (in 2014-2015, by $15.6 \%$ ), significant military expenditures (in 2016, increased to $7.1 \%$ of the state budget), and payments on external and internal debts (in 2017, amounts $30.3 \%$ of the state budget). Hence, the government, in agreement with the IMF, decided to increase fiscal pressure on the households through higher prices for natural gas supplied by the state monopoly named Naftogaz of Ukraine (NGU).

NGU is a monopolistic state-owned holding company, it is composed of a multitude of subsidiaries specializing in domestic oil and gas exploration and production, gas imports, storage, gas transit from Russia to Europe, and domestic distribution. Households, industries, and budget institutions all purchase gas from NGU for direct use.

The changes in the operating profitability of NGU and regional gas distribution companies (GDCs) are shown in Figure 2.

After the drastic price growth in 2015-2017, the monopolist's operations become extremely profitable. Net sales of NGU increased by 2.5 times for three years up to 6.25 billion euros and net profit reached 1.3 billion euros in 2017. For a company with 700 employees, this amount seems excessive. Hence, the excess income was spent on paying high bonuses to the top management of NGU and the state budget revenue. Regional gas distribution companies-monopolists have also experienced

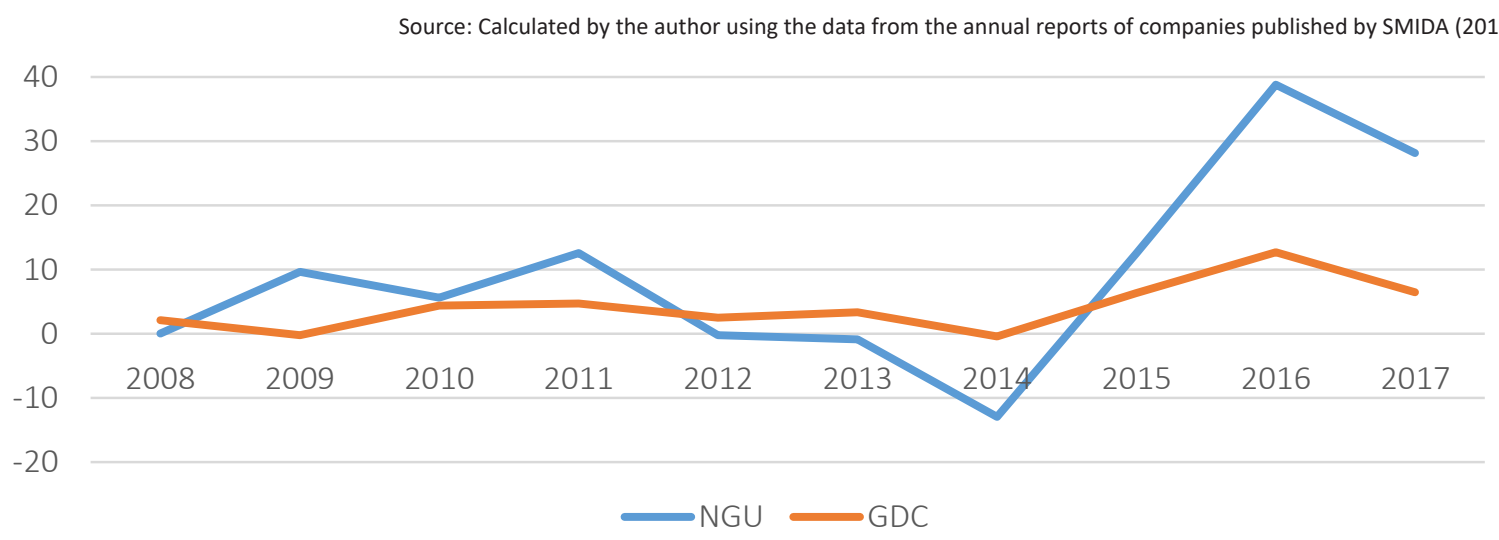

Figure 2. Operating profitability of NGU and regional GDCs, \% 
50
40
30
20
10
0

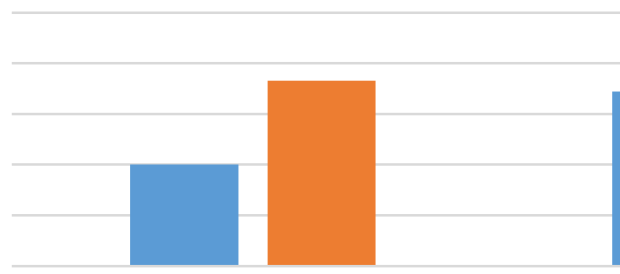

Below 100 euros

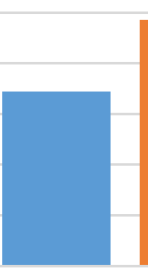

100-170 euros

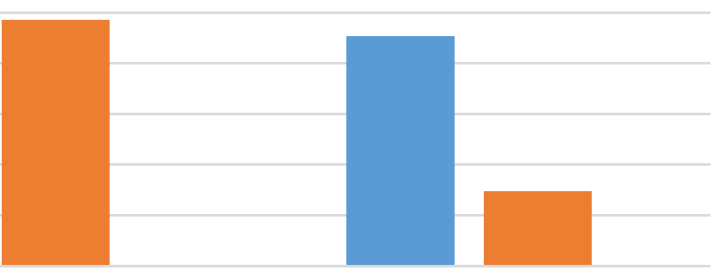

Over 170 euros

[ $2013 \quad 2017$

Figure 3. Distribution of Ukrainian people by monthly income per capita in 2013 and 2017, EUR

multiple increase profitability and revenues, which also partly expanded the state budget revenue.

\subsection{Natural gas as a taxation tool}

According to our calculations, based on the data from STSU (2018), thanks to this gas fiscal tool, the state budget of Ukraine in 2017 added about 2 billion euros, accounting for about $8 \%$ of all the budget revenues. Thus, the new gas tax can be ranked fourth among the traditional Ukrainian taxes, second only to income tax (11\%), excise duties (9\%), and VAT (50\%).

Further, the attempt was made to find out how fair this gas tax is.

In fact, almost all the Ukrainian households depend on natural gas. Some of them use gas for cooking, the others use a gas-fired heating system. Ukraine has a relatively cold climate and heating system is applied here during 5-6 months a year. This requires high energy consumption, primarily of natural gas.

Besides, Ukraine is one of the poorest countries in Europe (World Bank, 2018). In 2016, 58.4\% of people of this country had an income below the official subsistence minimum - poverty line (State Statistics Service of Ukraine, 2018). So, when the level of material deprivation for $28 \mathrm{EU}$ countries is about $16 \%$, and the deep material deprivation $8 \%$ (Eurostat, 2018), in Ukraine, these indicators in 2017 accounted for $42 \%$ and 27\%, respectively (State Statistics Service of Ukraine, 2018).

So, after the drastic price growth, the average share of utility costs in the structure of total household expenses in Ukraine increased from 8.1\% in 2014 to $15.4 \%$ in 2017 (State Statistics Service of Ukraine, 2018). However, was this increase uniform and equivalent for all groups of the population?

According to the utility subsidies calculator (Teplo, 2018), a Ukrainian can count on partial state aid (subsidy) in 2018 if his monthly income does not exceed 7,778 UAH or about 244 euros. In September 2018, this amount was 14\% below than an official average salary in Ukraine (State Statistics Service of Ukraine, 2018). Considering that only 7.6 million people of the 42 million population of Ukraine are officially employed, it can be assumed that the average income per resident is significantly lower than an average salary. Indeed, if it looked at the average household income in 2017, it was only 8,165 UAH for an average of 2.58 people in household (State Statistics Service of Ukraine, 2018). Hence, the monthly income per resident of Ukraine in 2017 was 3,165 UAH or 105 euros. This means that the majority of the population of Ukraine should receive financial aid from the state in the form of utility subsidies.

Currently, only several industries in Ukraine pay an official salary above an average level: transport, manufacturing, financial sector, IT and telecommunications sector, professional, scientific, and technical activities, and state administration (State Statistics Service of Ukraine, 2018). According to Ukrainian standards, the employees of these industries can be considered a middle class, earning an average of 300 to 1,000 euros per month. So further in this study, a household with above 170 euros per capita will be considered as a middle-class household. 
During the time from introduction of the higher gas prices for households, the population structure by income level has changed dramatically (Figure 3).

While in 2013, the major group of the population were middle class and high-income people (45.4\%), and the poor group was the least numerous, for the next 4 years, the middle and high-income class have gone down and now amounts for only $14.8 \%$ of the population of Ukraine. The main reasons for such a radical framework shift can be seen in the economic fall and increased tax pressure on the economy and citizens. So, the share of budget revenues in GDP increased from $29 \%$ up to $35 \%$, including a new tax on gas consumption ("gas tax").

\subsection{A case of the "gas tax"}

In terms of subsidizing the poor group and the group with lower-middle incomes, the main burden of this gas tax was laid down on the middle class, since for rich people, these amounts are not significant.

The consequences can be seen in Figure 4 and Figure 5 on a case with four different income families and ceteris paribus: 80 euros utility rate for a $50 \mathrm{~m}^{2}$ apartment for a two-people household.

Currently, a relatively small group of residents (below $15 \%$ ) actually pays for the majority of heating and gas consumed by all the households. And the middle-class household pays the most of this gas

Source: Author's calculation using Teplo (2018).

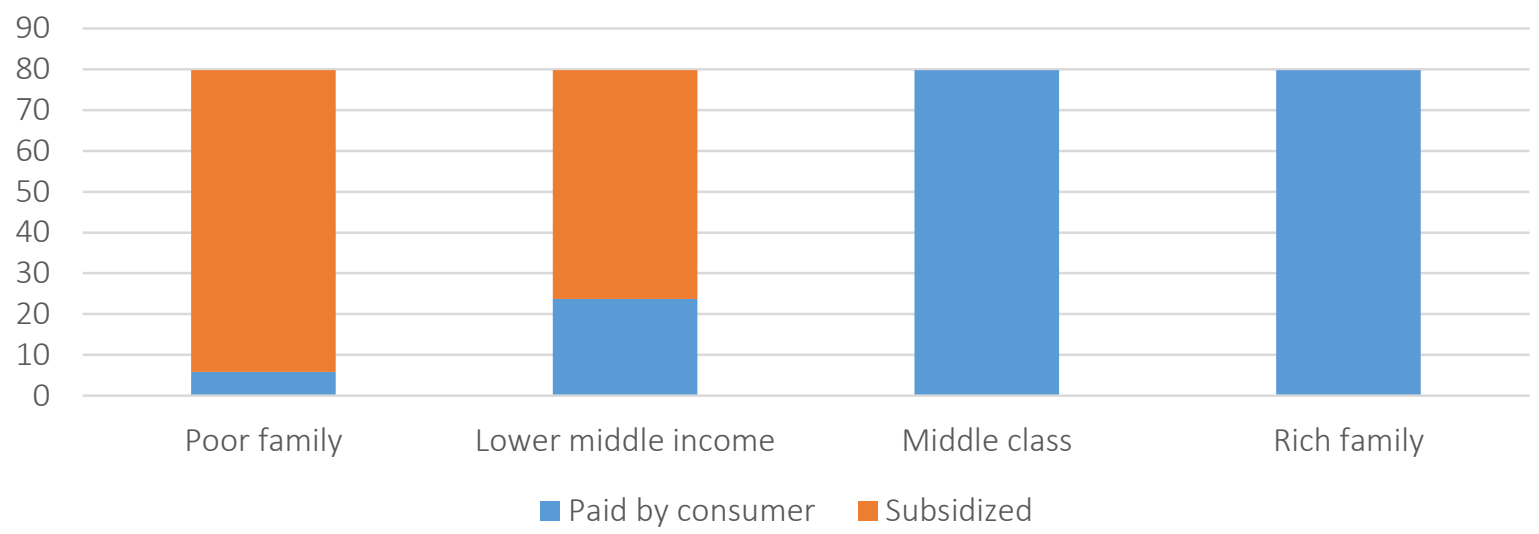

Figure 4. Four cases of utilities rate structure in Ukraine for the same apartment, euros

Source: Author's calculation using Teplo (2018).

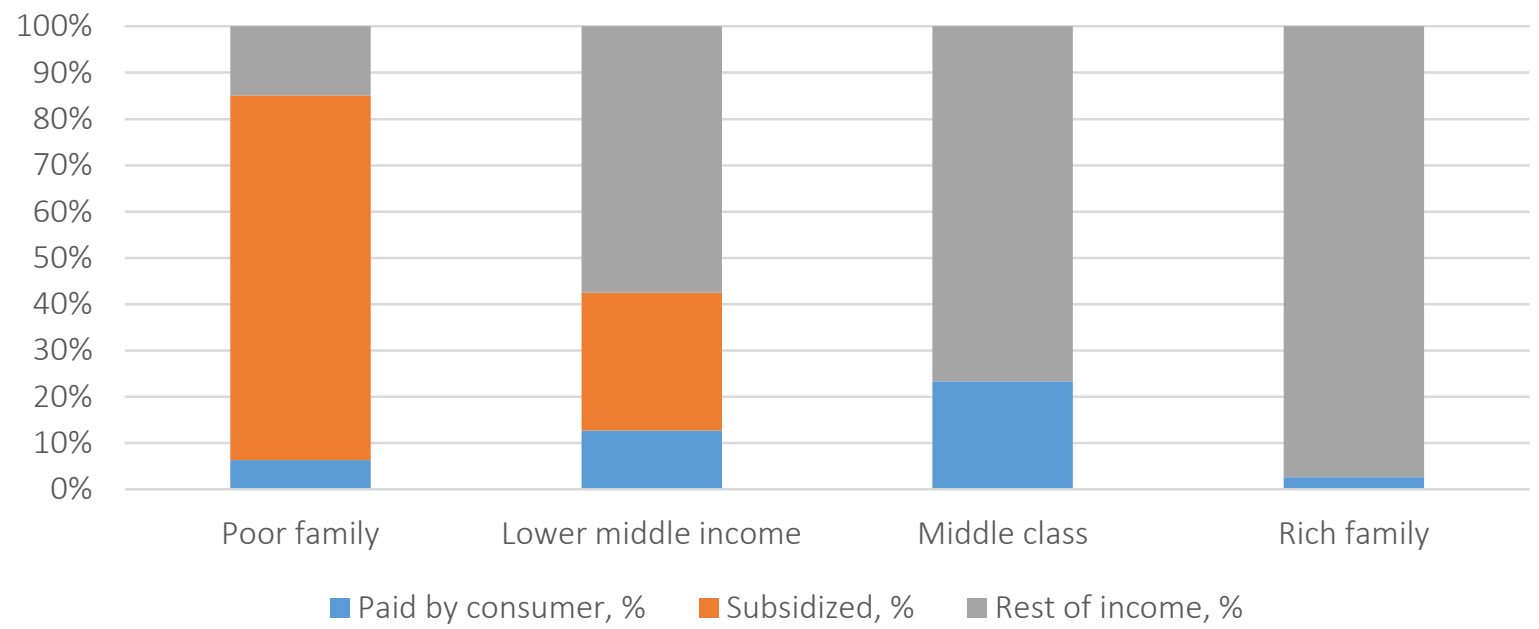

Figure 5. Four cases of the share of utility rate in monthly household income, $\%$ 
tax in a percentage of the monthly household income (above 23\%), but the same amount as a reach family that is below $3 \%$ of its monthly income.

This case shows an obvious bias of the current gas taxation system in favor of poor and rich consumers, which pay a small part of their income for utilities. In such a system, the middle class remains at the biggest loss. However, in our opinion, the most negative consequence of this system is the elimination of incentives for households with lower middle incomes to increase the income to reach the middle class. This system stimulates them to stay poorer to save the subsidies.

Apparently, the developers of the current system do not want the development of the middle class and the sustainability of the socio-political and economic systems of Ukraine.

\section{4."Shadow" and ethical aspects of the "gas tax"}

The government and supporters of the described gas tax system often highlight its expediency for legalizing hidden household incomes and reducing the shadow economy. Further the attempt was made to figure out how right they are.

Medina and Schneider (2017) found that, the average index of the shadow economy for 158 countries in 2015 was $28.7 \%$, and for Ukraine this index was about $43 \%$. It means that $43 \%$ of official GDP value earned in the informal sector of the economy without taxation and official salaries. The tax burden and institutional quality (corruption, level of justice, and law enforcement) are often called the main reasons for the existence and growing the shadow economy (Kirchgässner, 2017; Buehn, Dell'Anno, \& Schneider, 2018). Hence, the higher tax burden mentioned above including the introduction of a gas tax in Ukraine should increase the shadow economy in that country. However, on the contrary, the Ukrainian government does not try to reduce corruption and the tax burden. It has chosen another way - taxing the expenses of all households with the support of the poorest of them with utility subsidies. However, this way has several shortcomings, among which the following ones can be highlighted:
1. The growth in cost inflation. High dependence of Ukrainian economy on a natural gas that applies in the majority of businesses for production (in the chemical industry), heating and consumption, makes it sensitive to a change the prices of natural gas (Goncharuk, 2013).

2. Reduction in domestic consumption. Rising costs for utilities lead to a reduction in household (especially poor and lower middle income) consumption of goods and other services.

3. Reducing the profitability of domestic business. Higher gas prices lead to higher cost of production and utility cost. Some businesses get losses because of the high prices of natural gas, i.e. chemical industry and metallurgy (see in Goncharuk, 2015). On the other hand, lower consumption due to higher gas prices for households can shorten sales of certain consumer goods and services.

4. Reducing the middle class and increasing the stratification of society. This trend is shown in Figure 3. Its continuation is fraught with increased tensions and the lumpiness of society.

5. Concealment of real incomes and growth of the shadow economy. When one gets a utility subsidy due to a low income, it stimulates to hide the actual incomes to save more money for living. In a corrupt system with the low institutional quality, this counterargument to government expectations may cancel out its attempts to fill the budget at the expense of shadow incomes of households.

However, in our opinion, the main challenge of such gas tax has an ethical aspect. Its meaning is as follows. People, who honestly work in the formal sector of the economy earn good money and pay taxes in full, under such a system should pay not only for themselves but also for those people who hide their income and do not want to pay taxes. The corrupt system of state fiscal control cannot identify and punish the latter. Hence, they feel comfortable in the new system with a gas tax. This cannot be said of honest taxpayers who are forced to tighten their belts and restrict their consumption of goods and services. 
When a neighbor living in the same apartment pays for the same service much less, just because he indicated a low income in the declaration, an ethical project emerges - the injustice of pricing and taxation.

Under the conditions of economic recession and increasing tax pressure, honest taxpayers tend to migrate to the EU countries in search of decent wages, standards of living and justice. Here another problem arises that is aggravated by the gas tax - the problem of labor migration abroad when people are fleeing from injustice and hard life.

\section{DISCUSSION}

Sometimes people make mistakes for a good cause. However, sooner or later these mistakes need to be corrected. Otherwise, a good cause can turn into a disaster. When the Ukrainian government in 2014 turned to the IMF for aid, it pursued noble goals to save the country's economy from default and preserve some kind of financial stability in conditions of military conflict and recession. However, a corrupt system requires more and more resourc- es that are used inefficiently, which leads to new needs. At some point, this system loses its balance and begins to absorb itself. The desire to save a face while poorly managed and unsuccessfully reforming the economy forced the Ukrainian government out of the crisis at the expense of the middle class - households that pay taxes and are the base of sustainability of any state. Moreover, it came up with a taxation tool that would benefit the poorest and richest households. The authors named it the "gas tax." This tool was introduced three years ago by the increasing price of gas and heating services for households with utility subsidies for poorest of them.

However, the government did not consider that in a corrupt system, consumers can also be dishonest. As a result, the number of households in need of utility subsidies increased from $29 \%$ in 2016 to $46 \%$ in 2017. Currently, over half of all the Ukrainian households get utility subsidies. It turns out the honest taxpayers who receive middle incomes (middle class) are in the most disadvantaged position because forced to pay the highest price and the largest share of their income for utilities.

\section{CONCLUSION}

This study enabled to distinguish several shortcomings and ethical problems that appeared during the application of the gas tax in Ukraine. Among them the following are apparent:

- growth of cost inflation;

- reduction in domestic consumption;

- reducing the profitability of domestic business;

- reducing the middle class and increasing the stratification of society;

- concealment of real incomes and growth of the shadow economy;

- enhancing injustice and a labor migration abroad.

All these problems are the arguments for reconsidering new taxation tool named "gas tax" to make it fair and less painful for the economy and households. Otherwise, this tool will further destroy the middle class and limit the growth potential of the Ukrainian economy.

This study found that using natural gas as a taxation tool, the government transfers the largest tariff burden to middle-income households. However, the poor households are supported by a gigantic amount of government subsidies, the size of which is comparable to all government spending on health care and education in Ukraine.

The results of this study are important primarily for policymakers who are trying to use gas or other energy markets for purposes other than ensuring their efficiency. The case study under consideration 
will be useful both to fiscal authorities and gas market regulators who have leverage to influence the gas prices and managing their consumption.

\section{ACKNOWLEDGMENT}

This article is based upon the work from COST Action 'European Energy Poverty: Agenda Co-Creation and Knowledge Innovation' (ENGAGER 2017-2021, CA16232) supported by the COST (European Cooperation in Science and Technology).

\section{REFERENCES}

1. Bollino, C. A., \& Botti, F. (2017, December). Energy Poverty in Europe: A Multidimensional Approach. PSL Quarterly Review, 70(283), 473-507. Retrieved from https://ojs.uniromal.it/index. php/PSLQuarterlyReview/article/ view/14155

2. Bouzarovski, S. (2014). Energy poverty in the European Union: landscapes of vulnerability. Wiley Interdisciplinary Reviews: Energy and Environment, 3(3), 276-289. https://doi.org/10.1002/wene.89

3. Bouzarovski, S., \& Tirado Herrero, S. (2017). The energy divide: Integrating energy transitions, regional inequalities and poverty trends in the European Union. European Urban and Regional Studies, 24(1), 69-86. https://doi.org/10.1177\%2F0969776415596449

4. Buehn, A., Dell'Anno, R., \& Schneider, F. (2018). Exploring the dark side of tax policy: an analysis of the interactions between fiscal illusion and the shadow economy. Empirical Economics, 54(4), 16091630. Retrieved from https:// papers.ssrn.com/sol3/papers. cfm?abstract_id=2643339.

5. Duvignau, R. (2015). IMF aid package pushes Ukraine gas prices up $280 \%$. Reuters. Retrieved from https://on.rt.com/4y8rxq

6. Eurostat (2018). Income and living conditions. Retrieved from http://ec.europa.eu/eurostat/web/ income-and-living-conditions/ data/database

7. Goncharuk, A. G. (2013). What Causes Increase in Gas Prices: The Case of Ukraine. International Journal of Energy Sector Manage- ment, 7(4), 448-458. https://doi. org/10.1108/IJESM-03-2013-0003

8. Goncharuk, A. G. (2015). Natural Gas Stakeholders during Price Growth: A Case of Ukraine. International Journal of Energy Sector Management, 9(1), 94104. https://doi.org/10.1108/ IJESM-04-2014-0004

9. Goncharuk, A. G., \& lo Storto, C. (2017, February). Challenges and policy implications of gas reform in Italy and Ukraine: Evidence from a benchmarking analysis. Energy Policy, 101, 456-466. https://doi.org/10.1016/j. enpol.2016.10.037

10. Government (2018). Resolution of the Cabinet of Ministers of Ukraine "On Approval of the Provision on the Imposition of Special Responsibilities on the Natural Gas Market Actors for Provision of General Public Interests in the Process of Operation of the Natural Gas Market", No. 867 dated 19.10.2018, Legislation of Ukraine. Retrieved from https:// zakon.rada.gov.ua/laws/show/8672018-\%D0\%BF

11. Grave, K., Breitschopf, B., Ordonez, J., Wachsmuth, J., Boeve, S., Smith, M., \& Pudlik, M. (2016). Prices and costs of EU energy. Final Report, European Commission, ECOFYS Netherlands B.V.

12. Kirchgässner, G. (2017). On estimating the size of the shadow economy. German Economic Review, 18(1), 99-111. https://doi. org/10.1111/geer.12094

13. Krawczyk, D. A. (2016, September). Analysis of energy consumption for heating in a residential house in Poland. Energy Procedia, 95, 216-222. https://doi. org/10.1016/j.egypro.2016.09.053

14. Lenz, N. V., \& Grgurev, I. (2016). Energy poverty in Croatia: New Insights. In Proceedings of the 7th MAC 2016 (pp. 201-208). Retrieved from https://www.bib. irb.hr/818777

15. Medina, L., \& Schneider, F. (2017). Shadow economies around the world: New results for 158 countries over 1991-2015 (Working Paper, No. 1710). Johannes Kepler University of Linz, Department of Economics, Linz. Retrieved from https://papers.ssrn.com/sol3/papers.cfm?abstract_id $=2965972$

16. Mitra, P., \& Atoyan, R. (2012, October). Ukraine Gas Pricing Policy: Distributional Consequences of Tariff Increases (IMF Working Paper, WP/12/247). European Department, International Monetary Fund. Retrieved from https://www. imf.org/en/Publications/WP/ Issues/2016/12/31/Ukraine-GasPricing-Policy-DistributionalConsequences-of-Tariff-Increases-40047

17. NERC (2019). On establishment of tariffs on heating energy. The National Commission for state regulation in the energy and utilities (NKREKP), 10 December 2019. Retrieved from http://www.nerc.gov.ua/index. php?id $=37896 \&$ cpage $=2$

18. Perreault, T. (2008, July). Natural gas, indigenous mobilization and the Bolivian state (Identities, Conflict and Cohesion Programme Paper, 12). United Nations Research Institute for Social Development, Geneva. Retrieved from http:// 
www.unrisd.org/unrisd/website/ document.nsf/(httpPublications)/ D96F71885FB60F74C1257512002 F471E?OpenDocument

19. Pigliucci, M. (2016). RussoUkrainian Gas War: The Lack of a Common Strategy Jeopardizes European Unity. Advances in Economics and Business, 4(3), 124-131. Retrieved from http://www.hrpub. org/download/20160331/AEB211805530.pdf

20. Preotesi, M. (2016). Groups and Needs: Response of the Social Protection System in Nowadays Romania. Revista de Cercetare şi Intervenţie Socială, 55, 139-157. Retrieved from https://www.researchgate.net/ publication/316544935_Groups_ and_needs_Response_of_the_ social_protection_system_in_nowadays_Romania

21. Saha, S., \& Zaslavskiy, I. (2018, December). Advancing Natural Gas Reform in Ukraine (Discussion Paper). New York: Council on Foreign Relations. Retrieved from https://www.cfr.org/report/advancing-natural-gas-reform-ukraine

22. SMIDA (2018). Emitenty [Emitents]. Retrieved from https:// smida.gov.ua/db/emitent (In Ukrainian)

23. Stankova, O. (2018). IMF Executive Board Approves 14-month US\$3.9 Billion Stand-By Arrangement for Ukraine, US\$1.4 Billion for Immediate Disbursement. IMF Communications Department, International Monetary Fund. Retrieved from https://www.imf. org/en/News/Articles/2018/12/18/ pr18483-ukraine-imf-executiveboard-approves-14-monthstand-by-arrangement

24. State Statistics Service of Ukraine (2018). Demohrafichna ta sotsialna statystyka/Dokhody ta umovy zhyttia [Demographic and social statistics/Income and living conditions]. Retrieved from http://www.State Statistics Service of Ukraine.gov.ua/ operativ/menu/menu_u/virdg.htm (In Ukrainian).

25. STSU (2018). Richnyi zvit pro vykonannia Derzhavnoho biudzhetu Ukrainy za 2017 rik [Annual report on Ukrainian budget 2017 implementation]. Retrieved from https://www.treasury.gov. ua/ua/file-storage/richniy-zvitpro-vikonannya-derzhavnogobyudzhetu-ukraini-za-2017-rik (In Ukrainian)

26. Teplo (2018). Kalkuliator komunalnykh vytrat ta subsydii [Utility and subsidy calculator]. Retrieved from https://teplo.gov.ua/calculation (In Ukrainian)

27. Thomas, S., \& Rosenow, J. (2019). Drivers of increasing energy consumption in Europe and policy implications. Energy Policy (In press). https://doi.org/10.1016/j. enpol.2019.111108

28. Tymoshenko, Y. (2018). The gas tariff increase is a crime against one's own people. Official site by Yulia Tymoshenko. Retrieved from https://www.tymoshenko.ua/en/ news-en/the-gas-tariff-increaseis-a-crime-against-one-s-ownpeople/ (accessed on October 20, 2018). 